\title{
Large soft-sediment deformation structures (SSDS) in the Permian Barren Measures Formation, Pranhita-Godavari Valley, India: potential link to syn-rift palaeoearthquake events
}

\author{
Biplab Bhattacharya* and Abhirup Saha
}

\begin{abstract}
Records of palaeoearthquakes in sedimentary rocks are often debated due to the potential confusion in distinguishing seismic versus aseismic trigger mechanisms causing liquefaction. The present paper documents some unique soft-sediment deformation structures (SSDS), characterized by their extremely large size, complex morphology and preservation in coarse-grained pebbly sandstone. The SSDS are present in the Permian Barren Measures Formation, a syn-rift depositional unit within the Lower Gondwana succession in the Pranhita-Godavari Valley, eastern Peninsular India. The $\sim 210 \mathrm{~m}$ thick succession is represented by stacked fining-up retrogradational cycles, characterized by coarse-grained trough cross-stratified pebbly sandstones near the base and fine-grained heterolithic sandstones-mudstones at the top. Each cycle signifies a change from fluvial- to tidal-influenced depositional systems. Coarse-grained pebbly sandstone beds near the base of each cycle record most SSDS, including complexly deformed layers, pseudonodules, load and flame structures, various water-escape structures like vertical/inclined sediment columns (sedimentary dykes) and contorted beds, and syn-sedimentary faults. The deformed beds are underlain and overlain by the undeformed beds. Complexly deformed SSDS are often sharply truncated at the top by undeformed beds manifesting syn-sedimentary character, which signifies that deformation took place just after deposition of the affected beds, but before deposition of the overlying beds while sedimentation was continuous. Facies analysis reveals the absence of processes like storms/pounding waves, slumps, rapid dumping (massive beds), impact shaking, volcanisms, tsunami waves or sediment gravity flows in the study area, thus negating their possibility as triggering agents for the liquefaction. The complex nature and large size of the deformation structures imply extensive liquefaction near the sediment-water interface. In addition, the deformed beds comply with most of the criteria of typical seismites. In half-graben type Gondwana basins, such seismites can be linked to palaeoearthquakes, which signify the phases of syn-rift fault reactivation, basinal sagging and associated accommodation changes.
\end{abstract}

Keywords: Large SSDS, Seismites, Fluvial-tidal, Syn-rift, Gondwana, Permian

\footnotetext{
*Correspondence: biplab.bhattacharya@es.iitr.ac.in; bb.geol.dgc@gmail.com

Department of Earth Sciences, Indian Institute of Technology, Roorkee
}

247667, India

\section{Springer Open}

(c) The Author(s). 2020 Open Access This article is licensed under a Creative Commons Attribution 4.0 International License, which permits use, sharing, adaptation, distribution and reproduction in any medium or format, as long as you give appropriate credit to the original author(s) and the source, provide a link to the Creative Commons licence, and indicate if changes were made. The images or other third party material in this article are included in the article's Creative Commons licence, unless indicated otherwise in a credit line to the material. If material is not included in the article's Creative Commons licence and your intended use is not permitted by statutory regulation or exceeds the permitted use, you will need to obtain permission directly from the copyright holder. To view a copy of this licence, visit http://creativecommons.org/licenses/by/4.0/. 


\section{Introduction}

Soft-sediment deformation structures (SSDS) formed by deformations in sediments or sedimentary rocks before significant diagenesis/lithification (Owen et al. 2011), are reported from sediments/sedimentary rocks of varied depositional environments, including, glacial, eolian, lacustrine, fluvial, alluvial, tidal flat, deltaic, estuarine, shore, shelf and deep marine slopes (Seilacher 1969; Rossetti 1999; Rodríguez-Pascua et al. 2000; Obermeier et al. 2005; Moretti et al. 2016). Such deformation features may develop by different processes including processes of liquefaction and fluidization, when primary stratification and grains are disturbed by a condition of increased pore fluid pressure exceeding the sediment strength (Allen 1977, 1982; Owen 1987). However, debates and discussions regarding the formation of various SSDS are long-standing (Seilacher 1969; Sims 1973; Lowe 1975; Allen 1982, 1985; Brodzikowski and Haluszczak 1987; Seth et al. 1990; Owen 1995; Obermeier 1996; Bhattacharya and Bandyopadhyay 1998; Bhattacharya and Bhattacharya 2010; Sarkar et al. 2014; Bhattacharya et al. 2016; Jha et al. 2017). Liquefaction is common in sediments of coarse silt to fine sand size (Owen and Moretti 2011). In coarser sediments, e.g., coarse-grained sand, pebbly sand, etc., these processes are relatively less common, although there are few examples of liquefaction in gravels associated with the high-intensity agents or the presence of important impermeable barriers (e.g. Lowe 1975; Postma 1983).

Triggering agents for liquefaction of multi-layered sediments may range from earthquake shocks, pounding waves during storms, meteorite impacts, sub-aqueous mass movement, shear stress along sediment-water interface, rapid sedimentation, overloading and upward movement of pore water/gas, volcanic activities, groundwater fluctuations, tsunami, etc. (Greb and Archer 2007; Owen and Moretti 2008, 2011; Moretti and Van Loon 2014). Although individual trigger mechanism does not leave any characteristic morphological/structural imprints during or after liquefaction, attempts to link these trigger mechanisms with seismic shocks ('seismite' layers), leading to the identification of palaeoearthquake events in the rock record, are very common (Seilacher 1969, 1984; Lowe 1975; Seth et al. 1990; Pratt 1994; Owen 1995; Bhattacharya and Bandyopadhyay 1998; Owen and Moretti 2011; Moretti and Van Loon 2014; Van Loon 2014). Such indiscriminate attempts have led to a lot of terminology confusion, diluting the actual aim/goal of identifying these structures.

Following Owen and Moretti (2011), sedimentary units are identified as seismites when: (1) they develop close to syn-sedimentary faults, which may generate earthquakes as potential triggers; (2) their deformation features are consistent with those having a known seismic origin; (3) they show lateral continuity over long distances; (4) they manifest gradual increase in intensity and frequency of deformations towards the epicenter; and, (5) they are characterized by stratigraphic repetition of deformed layers, separated by undeformed layers. However, there are many controversies and contradictions to this view in terms of (i) insufficient actual data from recent and its correspondence to the ancient; (ii) lateral continuity of the structures; (iii) vertical repetitions in the succession; and, (iv) relationship between the earthquake magnitude and the morphology of the resultant deformation structures (Moretti and Van Loon 2014), which raise the question regarding the absolute necessity of abiding to all of the above criteria to qualify as a seismite layer in the ancient rock record.

The trough cross-stratified, coarse-grained pebbly sandstone of the Permian Barren Measures Formation contains excellently preserved soft-sediment deformation structures (SSDS). These structures are unique since they are large and complex, and are abundant in very coarse-grained sediments (pebbly to gritty sandstone). A few reports of the very large SSDS in coarse-grained sediments are available in the literature (see, Alfaro et al. 2010). Such large and complex structures within coarser clastics raise a big question regarding their mode of origin and the nature of their trigger mechanism, which are addressed in the present paper. The goal of this study is to examine the possible link between the inferred liquefaction processes to palaeoearthquake events. Such a link will add a new characteristic in defining the seismite deposits irrespective of whether all other required parameters are fulfilled or not. In addition, the results and interpretations will contribute to the understanding of the nature of sedimentation and the palaeodepositional conditions in the overall context of the tectonostratigraphic paradigm of Gondwana basins.

\section{Geological background}

A thick sequence of the Gondwana Supergroup sediments was deposited from the Late Carboniferous to the Late Cretaceous (approximately for $200 \mathrm{Ma}$; Maulik and Chaudhuri 1983; Sharan and David 2016) on the Proterozoic basement rocks in the Pranhita-Godavari Valley (Fig. 1), India. The basin occurs as a NW-SE trending mega-lineament formed as a result of intra-cratonic rifting within the supercontinent Gondwana, in the Indian Plate. An overview of the simplified lithostratigraphy of the Gondwana Supergroup in the Pranhita-Godavari Valley is given in Table 1.

Gondwana sedimentation in the Pranhita-Godavari Valley started in the Late Carboniferous, with deposition of sediments in the pre-rift and syn-rift phases of a faultbordered downsagging basin (Lakshminarayana 1996; Biswas 2003). Biswas (2003) identified six distinct stages 


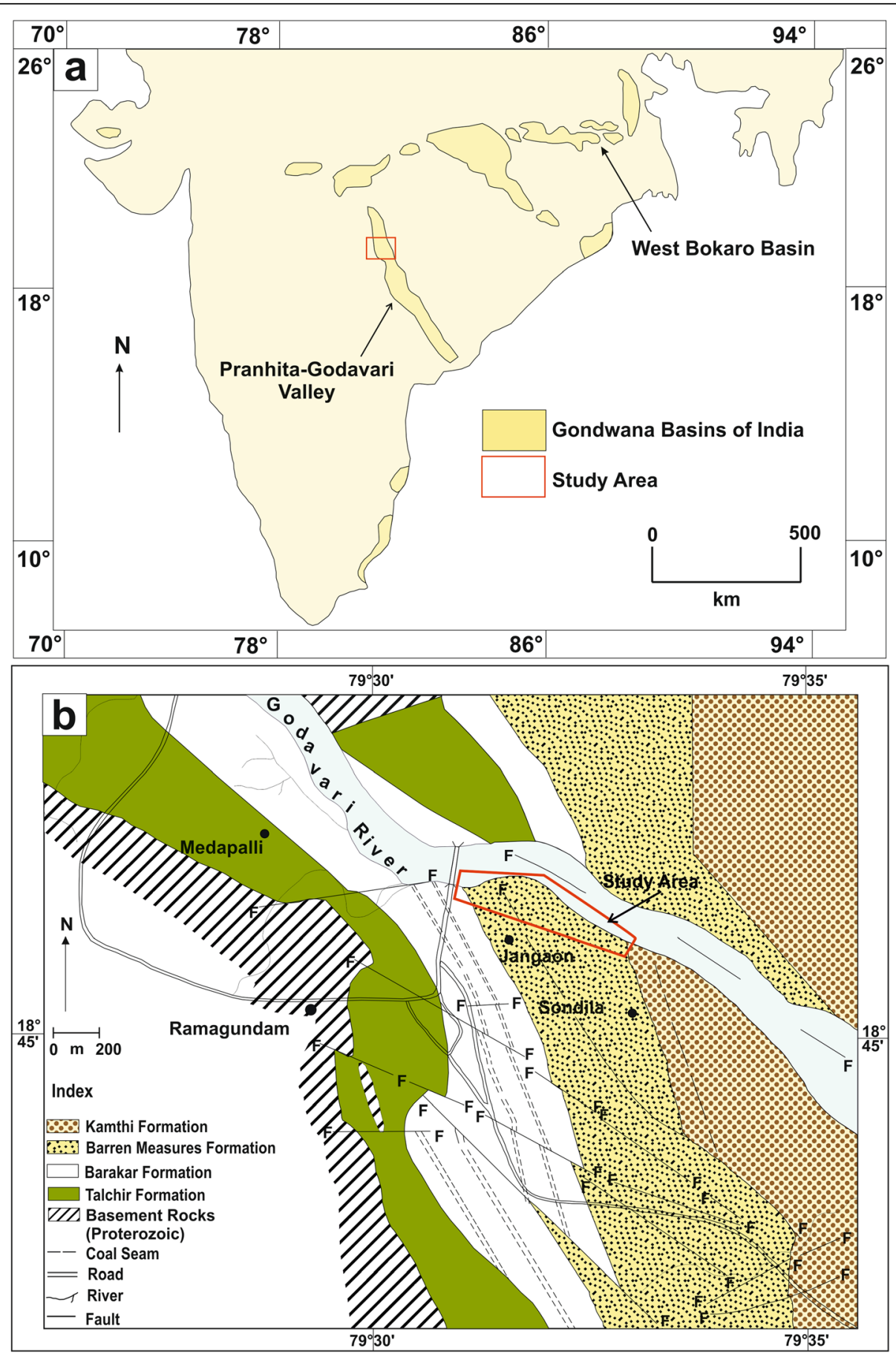

Fig. 1 a Map of southern part of the Peninsular India showing the distribution of Gondwana basins. Locations of the West Bokaro Basin, PranhitaGodavari Valley and the study area are marked; b Detailed geological map of north-western part of the Pranhita-Godavari Valley (after Raja Rao 1982) showing the distribution of different Gondwana litho-units. The present study was carried out on the Barren Measures Formation (marked as the study area) exposed along the southern bank of the Godavari River

in rift development and sedimentation, as mentioned in Table 1. Since the entire sedimentation took place in a passive margin intra-cratonic rift setting, magmatic activities were entirely lacking.
The succession of the Lower Gondwana Group took place simultaneously with rifting, along with the formation of several intrabasinal horsts and grabens (Biswas 2003; Bhattacharya and Bhattacharya 2015). Distinct sediment 
Table 1 Simplified lithostratigraphy of the Gondwana Supergroup in the Pranhita-Godavari Valley (after Sengupta 2003). Inferred sedimentation and tectonic cycles are merged, following Biswas (2003)

\begin{tabular}{|c|c|c|c|c|c|}
\hline Age & Group & Formation & Characteristic lithology & $\begin{array}{l}\text { Sedimentation } \\
\text { cycle }\end{array}$ & $\begin{array}{c}\text { Tectonic } \\
\text { cycle }\end{array}$ \\
\hline $\begin{array}{c}\text { Early } \\
\text { Cretaceous }\end{array}$ & \multirow{5}{*}{$\begin{array}{l}\text { Upper } \\
\text { Gondwana } \\
\text { Group }\end{array}$} & $\begin{array}{l}\text { Chikiala } \\
\text { Gangapur }\end{array}$ & $\begin{array}{l}\text { Conglomerate and } \\
\text { ferruginous sandstone } \\
\text { Coarse, ferruginous } \\
\text { sandstone and mudstone }\end{array}$ & Fluvial Cycle & $\begin{array}{l}\text { Upper } \\
\text { Gondwana } \\
\text { Rift Cycle }\end{array}$ \\
\hline Early Jurassic & & Kota & $\begin{array}{l}\text { Sandstone, siltstone, clay } \\
\text { and limestone band }\end{array}$ & Fluvial Cycle-III & $\begin{array}{l}\text { Late Rift } \\
\text { Stage }\end{array}$ \\
\hline $\begin{array}{l}\text { Early to Middle } \\
\text { Triassic }\end{array}$ & & Dharmaram & $\begin{array}{l}\text { Coarse sandstone and red } \\
\text { clay } \\
\text { Red/purple clay and } \\
\text { sandstone } \\
\text { Ferruginous/calcareous } \\
\text { sandstone, minor red clay }\end{array}$ & Fluvial Cycle-II & \multirow[t]{3}{*}{$\begin{array}{l}\text { Rift Climax } \\
\text { Stage }\end{array}$} \\
\hline & & Yerrapalli & $\begin{array}{l}\text { Red/purple clay and } \\
\text { sandstone }\end{array}$ & & \\
\hline $\begin{array}{l}\text { Late Permian to } \\
\text { Early Triassic }\end{array}$ & & Kamthi & $\begin{array}{l}\text { Sandstone, ferruginous, } \\
\text { purple siltstone at base }\end{array}$ & Fluvial Cycle-II & \\
\hline Middle Permian & \multirow{3}{*}{$\begin{array}{l}\text { Lower } \\
\text { Gondwana } \\
\text { Group }\end{array}$} & $\begin{array}{l}\text { Barren } \\
\text { Measures }\end{array}$ & $\begin{array}{l}\text { Sandstone, ironstone and } \\
\text { clay band }\end{array}$ & $\begin{array}{l}\text { Post Glacial } \\
\text { Swamp }\end{array}$ & \multirow[b]{2}{*}{$\begin{array}{l}\text { Early Rift } \\
\text { Stage }\end{array}$} \\
\hline Early Permian & & Barakar & $\begin{array}{l}\text { Feldspathic sandstone, } \\
\text { carbonaceous shale and } \\
\text { coal }\end{array}$ & Fluvial Cycle-I & \\
\hline $\begin{array}{c}\text { Early Permian } \\
\text { Late } \\
\text { Carboniferous } \\
\end{array}$ & & Talchir & $\begin{array}{l}\text { Tillite, greenish shale and } \\
\text { sandstone }\end{array}$ & $\begin{array}{c}\text { Glacial } \\
\text { Lacustrine }\end{array}$ & $\begin{array}{l}\text { Pre-Rift Sag } \\
\text { Stage }\end{array}$ \\
\hline Precambrian & & Metamorpho & ed sedimentation and gneiss & basement rocks & \\
\hline
\end{tabular}

packages were deposited during different stages of rift evolution. The pre-rift stage during the Late CarboniferousEarly Permian was initially characterized by glacigenic sedimentation (the Talchir Formation; Table 1), followed by crustal sagging along weak zones with the development of basin-marginal and intra-basinal faults in response to postglacial isostatic adjustments (Bhattacharya et al. 2005; Bhattacharya and Bhattacharya 2015). Repeated sagging and stretching along the faults and weak zones during the early syn-rift phase led to a half-graben type basin, where the Barakar sediments were deposited during the Early Permian (Bhattacharya et al. 2012, 2018). The Barakar deposition was followed by an active rift stage when the rift expanded by successive half-graben faulting. During this stage, the Barren Measures Formation and younger sediments were deposited by successive fluvial cycles, associated with phases of tectonic slackening. Bhattacharya and Banerjee (2015) opined for a fluvial-marine mixed estuarine depositional setting in response to marine transgressions and fluvial-marine interactions during the deposition of the Barren Measures Formation from the West Bokaro Basin (see Fig. 1a) in eastern Peninsular India. However, such depositional settings and sedimentation patterns are yet to be reported from the Pranhita-Godavari Valley.

\section{Materials and methods}

The present study is carried out along the southern bank of the Godavari River in the north-western part of the Pranhita-Godavari Valley (Fig. 1b), where a thick $(\sim 210$ $\mathrm{m})$ succession of the Permian Barren Measures Formation is exposed (Fig. 2). The rocks generally dip towards $\mathrm{NE}$ at a gentle angle of $7^{\circ}-10^{\circ}$. Several faults have affected the exposed sections (Fig. 1b), which are often encountered in the form of smooth slickensides in the field. In the study area, the Barren Measures Formation is characterized by very coarse-grained, pebbly to gritty sandstones, 


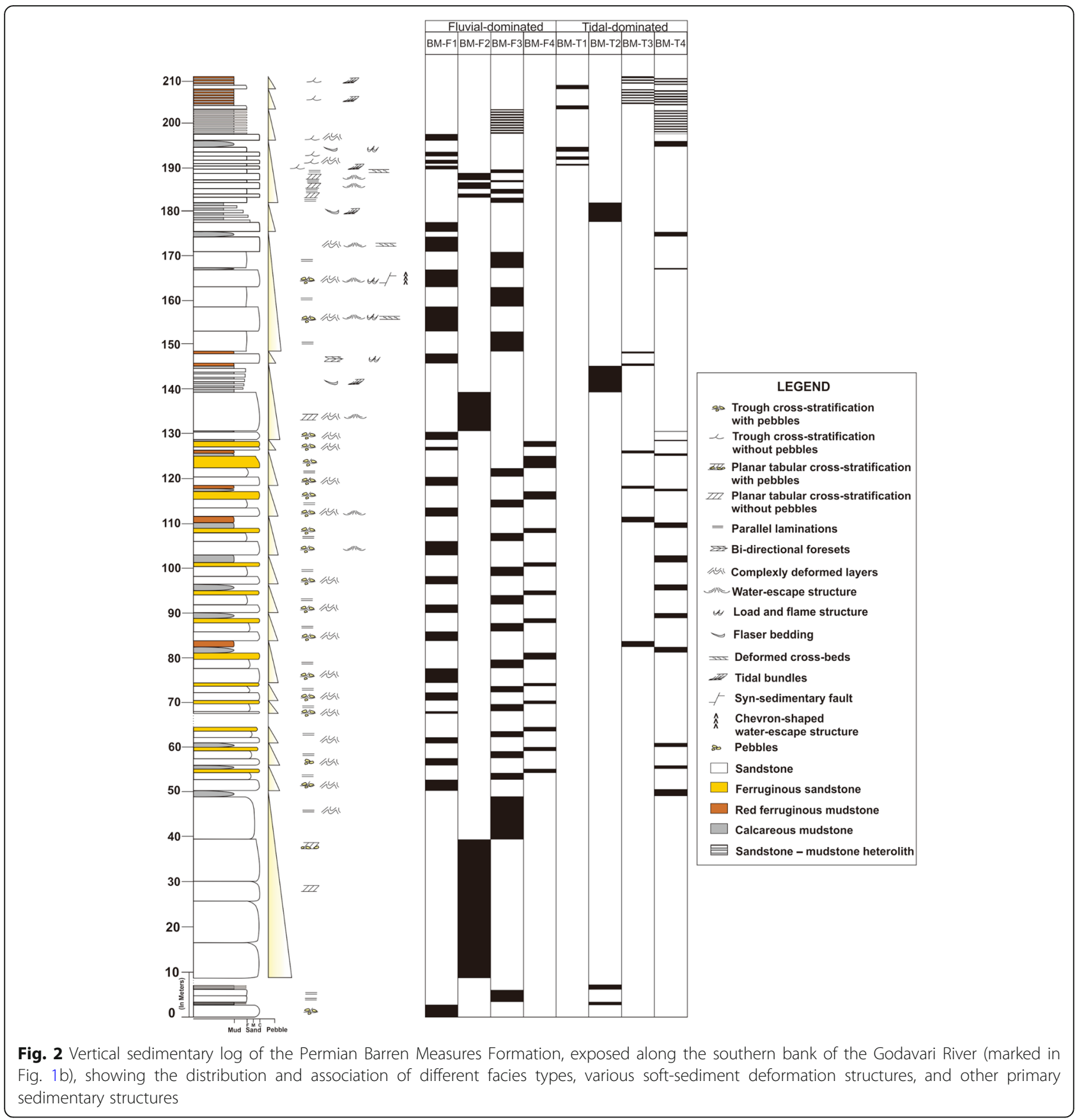

accompanied by medium- to fine-grained sandstones, ferruginous and carbonate-cemented sandstones and a few laminated to massive mudstones. The studied succession manifests multiple fining-up cycles (Fig. 2), starting with coarse-grained pebbly sandstones at the base of the cycle and fine-grained cemented sandstones or mudstones marking the end of the cycle, within an overall fining-up trend. More than twenty such fining-up cycles can be counted, showing varying facies architectures (Fig. 2). Marine sediments, in terms of intercalated tidal facies, are more common within the cycles near the upper part of the overall succession. Large-scale soft-sediment deformation structures (SSDS) are observed within the coarsegrained sandstones at the base of several fining-up cycles, mostly occurring around the middle part of the overall succession. Details of facies types and various SSDS are given in the successive sections.

\section{Results}

\subsection{Facies associations and depositional settings}

The Barren Measures Formation in the Godavari River section is represented by two predominant facies 

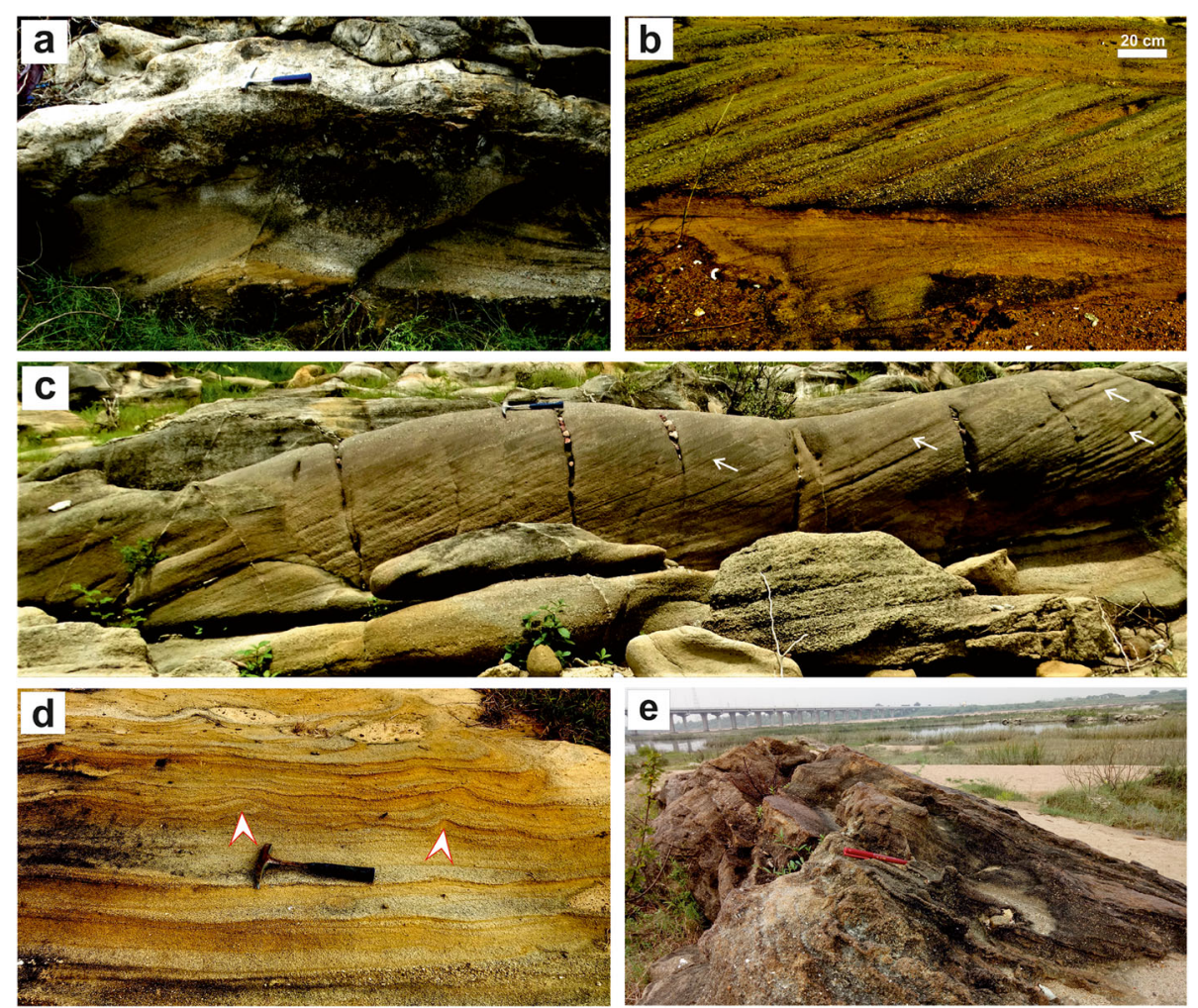

Fig. 3 Field photographs of the fluvial-dominated facies association (BM-F). a Pebbly, coarse-grained trough cross-stratified sandstone (BM-F1) with concentrations of pebbles as channel lag deposits; b Large cross-strata set within the planar tabular cross-stratified sandstone (BM-F2); C Laterally extended planar tabular cross-strata set within BM-F2. Note the presence of multiple accretion surfaces (arrows); d Pebbly, coarse-grained plane-bedded sandstone (BM-F3), showing normal grading of grain size. A few water-escape structures (arrows) have disturbed the plane beds locally; e Red, ferruginous pebbly cross-stratified sandstone (BM-F4). Length of the hammer in (a), (c) and (d) is $30 \mathrm{~cm}$; length of the pen in (e) is $14 \mathrm{~cm}$

associations, namely, a fluvial-dominated facies association (BM-F; Fig. 3) and a tidal-dominated facies association (BM-T; Fig. 4). Altogether eight facies types are identified within these two facies associations, appearing in cyclic repetition in the studied vertical succession (Fig. 2).

The fluvial-dominated facies association (BM-F) is characterized by pebbly, coarse-grained trough crossstratified sandstone (BM-F1; Fig. 3a), planar tabular cross-stratified sandstone (BM-F2; Fig. 3b, c) associated with pebbly, coarse-grained plane-bedded sandstone (BM-F3; Fig. 3d) and red, ferruginous pebbly crossstratified sandstone (BM-F4; Fig. 3e). The stacked, lenticular geometry of different cross-stratified sandstones with a concave-up base indicates the deposition from high-energy currents in channels. Concentrations of large pebble/cobble-sized clasts at the bottom of trough cross-stratified sandstone beds demarcate channel lag deposits (Fig. 3a). The predominance of coarse clasts with large trough cross-strata in the sandstones of the BM-F and relatively poor abundance of mudstones indicate channel-fill type deposition in a relatively high- energy river system. The poor sorting of the sediments with the mixing of coarse to fine, angular to rounded grains indicates short transportation from nearby sources.

The tidal-dominated facies association (BM-T) includes yellow sandstone facies (BM-T1; Fig. 4a, b), finegrained cross-stratified heterolithic facies (BM-T2; Fig. 4c), red ferruginous siltstone/mudstone facies (BM-T3; Fig. 4d, e), and white calcareous mudstone facies (BMT4; Fig. 4e). The facies types are characterized by a more sheet-like geometry, a relatively lower thickness and commonly represent the top of the fining-upward cycles. However, the sandstone-mudstone heterolithic facies and the mudstone facies become more pronounced and abundant towards the upper part of the overall succession (Fig. 2). Each facies type manifests definite signatures of tidal sedimentation in primary sedimentary structures. The yellow sandstone facies (BM-T1) and the fine-grained cross-stratified heterolithic facies (BM-T2) are characterized by laterally accreted foresets with mud drapes (tidal bundles; Fig. 4a, d), reactivation surfaces (Fig. 4a, b), lateral variations of the foreset thickness and 

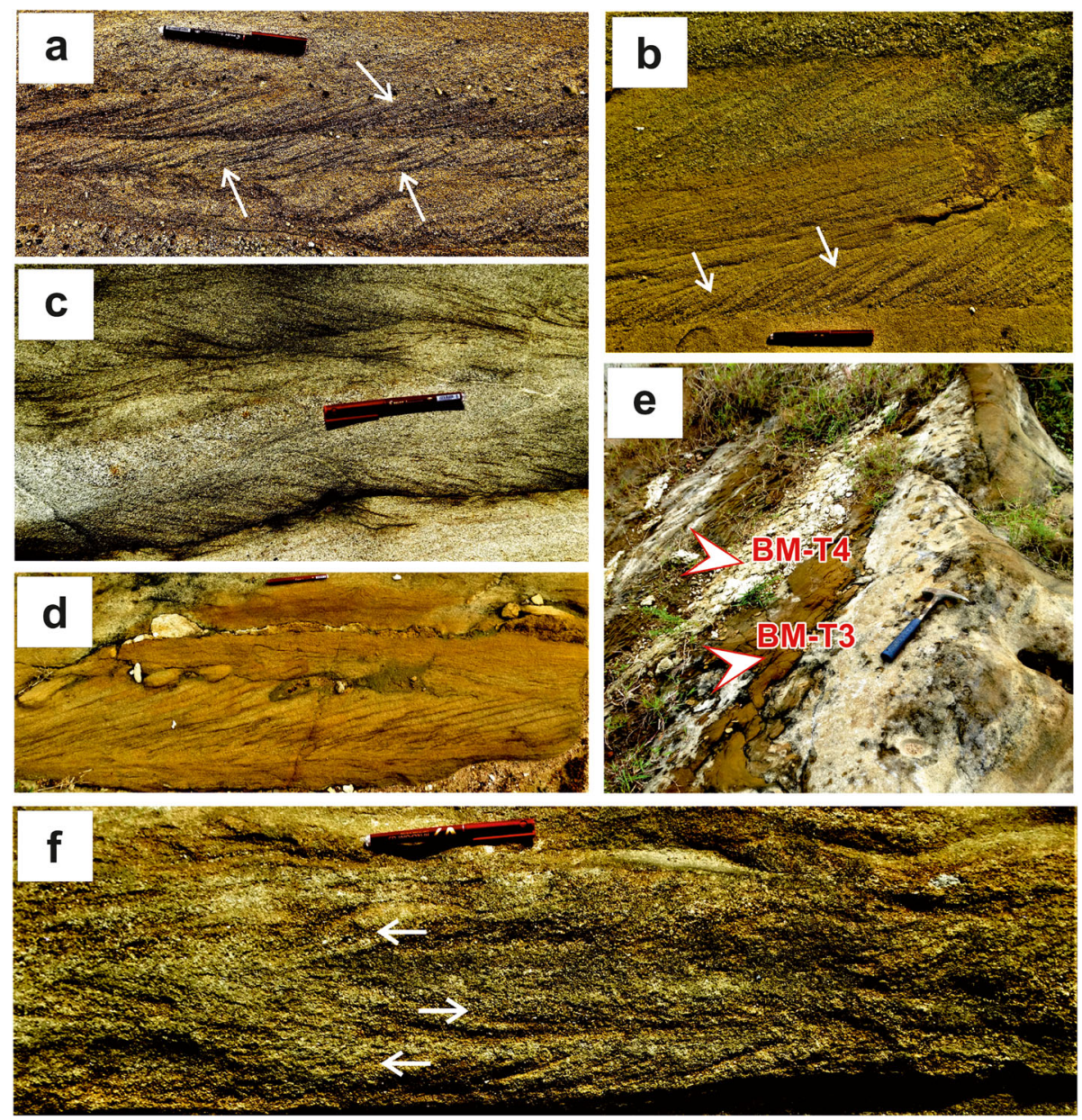

Fig. 4 Field photographs of the tidal-dominated facies association (BM-T). $\mathbf{a}$ and $\mathbf{b}$ Yellow sandstone facies (BM-T1) showing coset of cross-strata, formed of laterally accreted foresets with mud drapes (arrows); c Fine-grained cross-stratified heterolithic facies (BM-T2), showing tidal bundles and flaser beddings; d Red ferruginous siltstone/mudstone facies (BM-T3) with well-developed tidal bundles; e Red ferruginous siltstone/ mudstone facies (BM-T3) alternating with white calcareous mudstone facies (BM-T4); f Apparent bi-directionality of foresets (orientations shown by arrows) in vertically adjacent cross-strata sets in yellow sandstone facies. Pen in (a), (b), (c), (d) and (f) is $14 \mathrm{~cm}$ long. Length of the hammer in (e) is $30 \mathrm{~cm}$

frequency (Fig. 4a), cross-strata sets in opposite orientations (Fig. 4f), abundant flaser beddings (Fig. 4c), which unambiguously point towards the tidal control during deposition. Alternate traction and suspension deposition with thickness variation of the strata bundles manifest tidal fluctuations in different scales. All these facies types are characterized by intense cementation, both ferruginous and calcareous. Tidal bundles of different types are locally present within sandstone-dominated units in the facies BM-T3 (Fig. 4d). A massive to laminated whitegrey calcareous mudstone facies (BM-T4) occurs at the top of this facies association and demarcates suspension fall out of finer clastics in a relatively restricted, calm and quiet environment, possibly in a stagnant water body. The overall nature of these facies types signifies a mixed tidal-fluvial depositional environment for this facies association (BM-T). The facies association is devoid of wave ripples, hummocks, etc. in the study area, which signifies the absence of waves during the sedimentation.

From the bottom to the top of the studied succession, more than twenty fining-up cycles with thicknesses between $5 \mathrm{~m}$ and $20 \mathrm{~m}$ were recorded (Fig. 2). Each individual upward-fining cycle is characterized by (i) coarsegrained pebbly sandstone of BM-F1 or BM-F3 grading upwards into relatively fine-grained sandstone/siltstone/ mudstone of BM-T; (ii) other facies types, such as BMF2, BM-F4, BM-T1, BM-T2, recurring in between the cycle; (iii) signatures of tidal influence increasing from the bottom to the top of each cycle. Such almost uniform characters of each fining-up cycle, with a distinct change of the depositional setting from fluvial- 

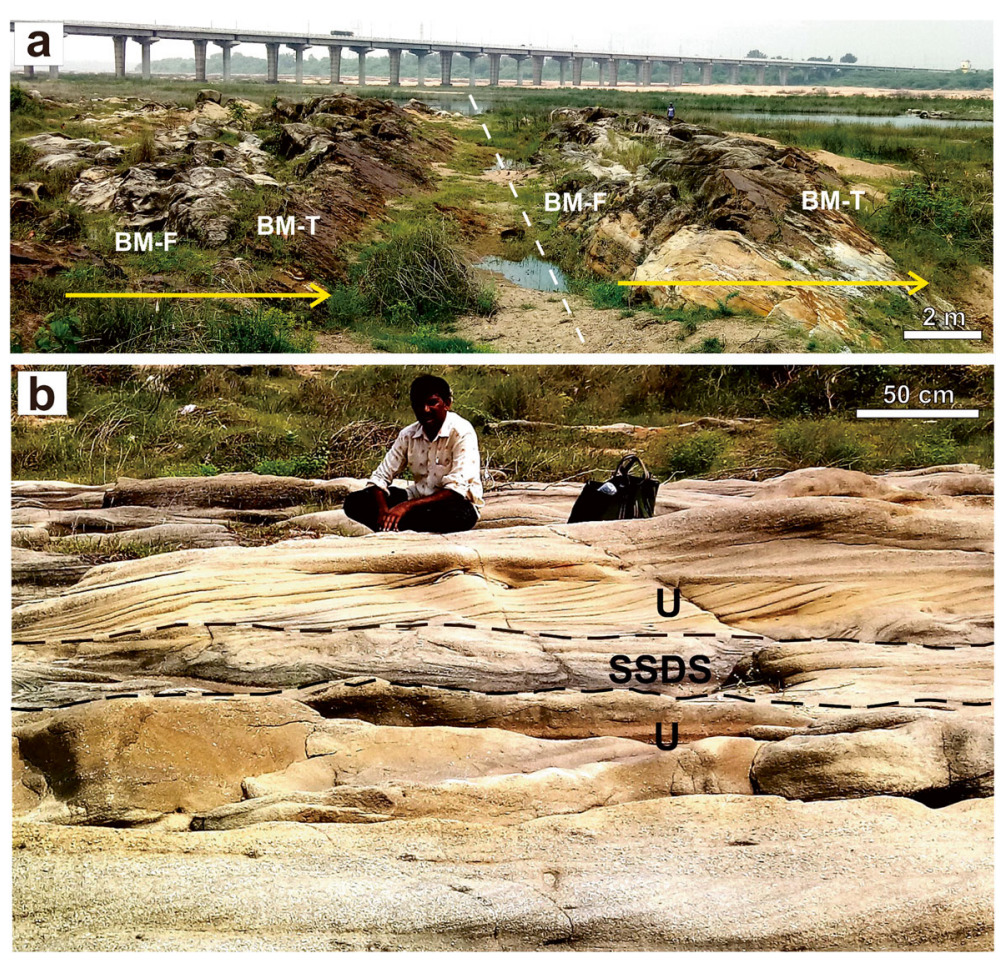

Fig. 5 a Field photograph showing two fining-up cycles with fluvial-dominated coarse-grained sediments in the lower part (BM-F) and tidaldominated finer sediments (BM-T) in the upper part of each cycle. The yellow arrows in each cycle mark the fining-up trend, and the white line marks the boundary between consecutive cycles; b Outcrop of a coarse-grained sandstone bed with distinct soft-sediment deformation structures (SSDS) underlain and overlain by undeformed, cross-stratified beddings (U)

dominated to tidal-influenced, signify a retrograding characteristic within each cycle. Such a retrogradational stacking pattern points to repeated transgressive events in short intervals. The presence of the mudstone facies of BM-T4, though of varied thickness, marks the end of each fining-up cycle and possibly indicates the maximum flooding during each short-term transgressive event. The overall succession also depicts a fining-up trend, with the predominance of the coarser, channelfill fluvial deposits (of BM-F) in the lower part, and finer, tidal-influenced marine deposits (of BM-T) towards the upper part. Relatively thicker fining-up cycles are observed in the lower part of the studied succession, whereas the upper part of the succession is characterized by frequent and thinner fining-up cycles (Figs. 2, 5a). Such a change from the fluvialdominated to the tidal-dominated depositional setting via multiple transgressive events indicates a transgressive estuarine depositional setting for the studied succession. The absence of wave-generated features discriminates the possibility of wave reconstruction in such a mixed fluvio-marine environment, and points to a tidal-influenced, relatively protected, estuarine depositional setting.

\subsection{Soft-sediment deformation structures}

Different types of soft-sediment deformation structures (SSDS) are recorded characteristically from the basal coarse-grained sediment beds, mostly present near the lower part of many fining-up transgressive cycles. Meanwhile, SSDS with relatively smaller size and less abundance also occur in the finer-grained tidal deposits in some of the cycles. Such SSDS-bearing beds are commonly underlain and overlain by undeformed beds (Fig. 5b). These structures are unique because (1) most of them are much larger and of less comparable morphology which are relatively rarely described in the literature (see Alfaro et al. 1997, 2010); (2) these mostly occur within the pebbly, very coarse-grained sandstone; (3) large SSDS involve the deformation of several crossstratified layers, where the normal grading from coarse pebbly sandstone to fine sandstone is present within individual foresets. However, large SSDS of varied origin are indicated by Alvarez et al. (1998), Debacker et al. (2001), Gibert et al. (2005), Alberti et al. (2017), and other researchers. Varied types of SSDS recorded in the study area are grouped and described under four distinct categories: (i) complexly deformed layers; (ii) load and flame structures; (iii) water-escape structures; and, (iv) 

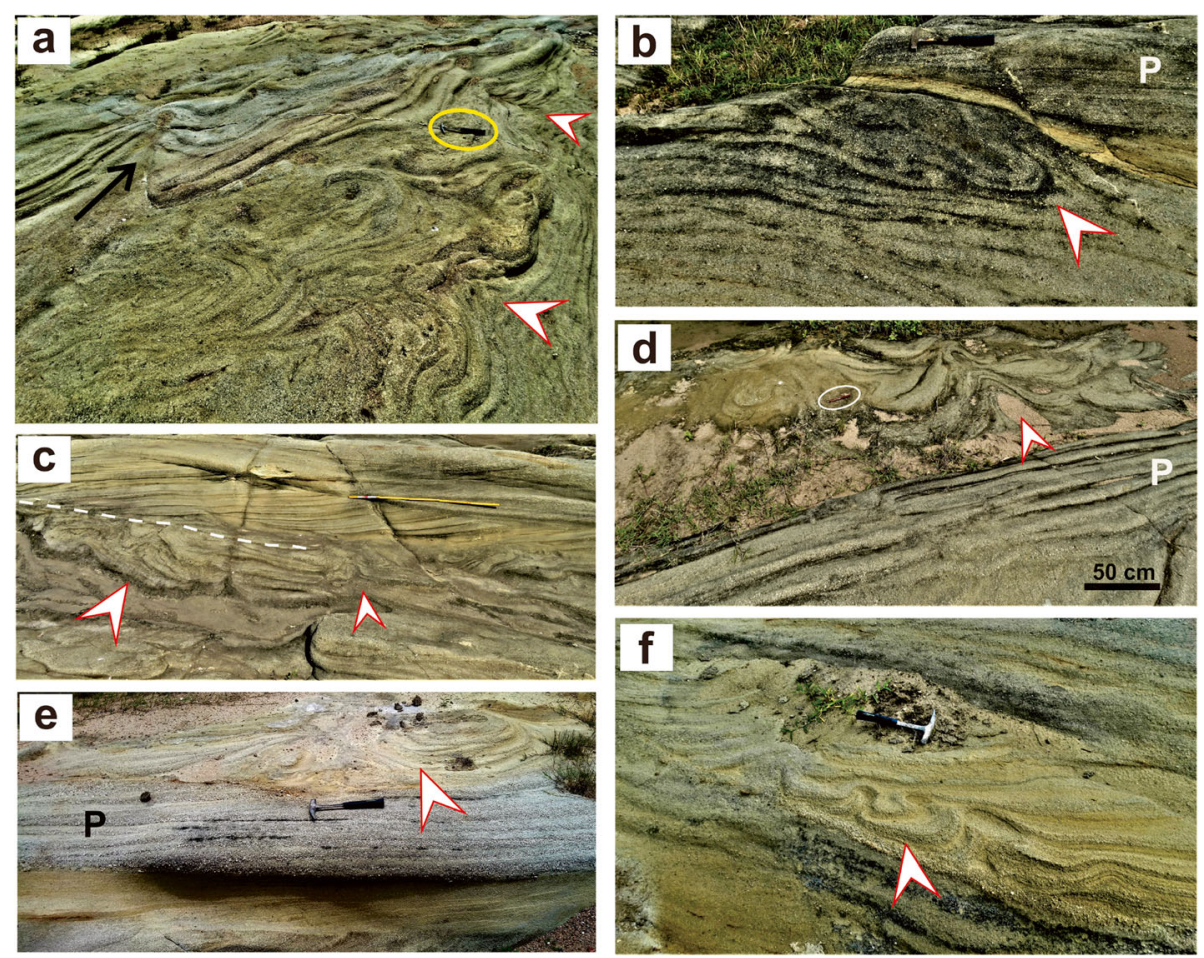

Fig. 6 Field photographs of various complexly deformed layers. a Large complexly deformed layers with multiple lobes (white arrows), separated by narrow flames. Note the presence of nearly-undeformed parallel-bedding in beds overlying the deformed layers. A small syn-sedimentary fault (black arrow) shows shifting of the parallel beds; b Inclined simple-deformed layers (arrow) with thin flames, in trough cross-stratified sandstone, are overlain by undeformed plane-bedded (P) sandstone; c Large complexly deformed layers, sharply truncated (along white line) against overlying cross-beddings in coarse-grained sandstone; d Multi-lobed complexly deformed layers (arrow) in sandstone developed on nearly undeformed plane-bedded (P) sandstone; e Large complexly deformed layers (arrow) developed on top of undeformed plane-bedded (P) coarsegrained sandstone; f Deformed lobes with flames developed in sandstone foresets. Note the absence of deformations in the overlying foresets within the same cross-bedding sets. Length of the hammer in $(\mathbf{a}),(\mathbf{b}),(\mathbf{e}),(\mathbf{f})$ is $30 \mathrm{~cm}$; length of the scale in $(\mathbf{c})$ is $1 \mathrm{~m}$

syn-sedimentary faults. Brief descriptions of the salient morphological features of each category of SSDS are presented below.

\subsubsection{Complexly deformed layers}

Large complexly deformed layers are the most abundant type of SSDS in the study area (Figs. 6, 7, 8). They are characterized by broad troughs like vertical to inclined lobes with extremely folded layers (Figs. 6, 7, 8), separated by mushroom- or flame-shaped vertical-to-inclined narrow sediment bodies (Figs. 6a, b, d, 7a, c, d). The width and height of the larger lobes can range up to $2.5 \mathrm{~m}$ and $1.6 \mathrm{~m}$ (Fig. 7), respectively; and these lobes mostly develop within pebbly, coarse-grained cross-stratified sandstones involving thick, graded foresets in a large cross-strata set or multiple sets (Figs. $6 \mathrm{~d}-\mathrm{f}, 7 \mathrm{a}-\mathrm{d}$ ). Within the lobes, layers are highly deformed and are characterized by several smaller partitioned lobes and interlobes (Figs. 6a, c, d, 7ac), symmetric to asymmetric pairs of lobes and isolated kidney-shaped bodies ('pseudonodules' of Owen 2003; Fig. $7 \mathrm{~d})$. The sediments in the interlobe flames show a complete mixing, as it ranges from pebbles to fine-grained sandstones and does not contain any preserved laminae. The folds on thick foresets are very smooth and show a thickness variation of the deformed layers from below the trough to the fluid-escape channel (Fig. 7a, d). Locally, large lobes of complexly deformed layers are preserved, which contain foresets deformed with simple, complex and overturned folds within the cross-strata sets (Figs. 6b, $\mathrm{f}, 8 \mathrm{a}$ ). Relatively smaller lobes (with width of up to $0.8 \mathrm{~m}$ and height of $0.5 \mathrm{~m}$ ) are observed in fine-grained heterolithic facies, where again the foresets in cross-strata sets are extremely deformed (Fig. 6c). Most of the deformed layers are truncated at the top, commonly by an erosional surface or by deposition of completely undeformed beds (Fig. 8). Though the coarse-grained sandstone beds bearing such large complex deformations are laterally persistent in the study area for more than $50 \mathrm{~m}$, the intensity of deformations of the foresets varies laterally and may range from negligible to extreme deformation (Fig. 6f). Locally, foresets within thick coarse-grained cross-bedded sandstones are deformed to varying degrees producing overturned (Fig. 9a), partly contorted (Fig. 9b), 'S'shaped (Fig. 9c), or completely homogenized (Fig. 9d) 

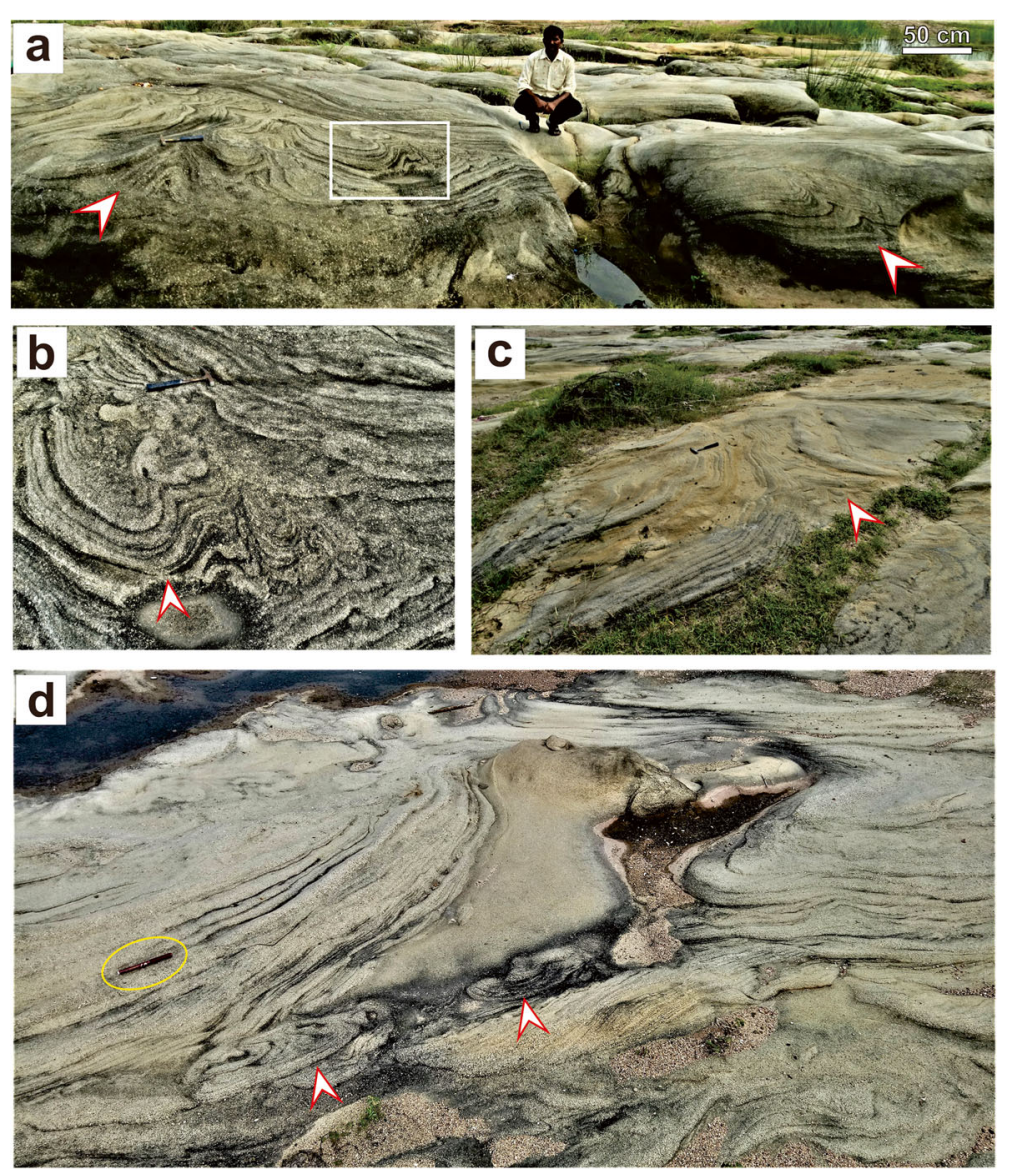

Fig. 7 a Very large complexly deformed lobes within trough cross-stratified sandstone showing asymmetric folding of the lobes (arrows); b The enlarged area of outcrop under the white rectangle in a, showing details of the complexly deformed layers; c Meter-scale complex deformation within trough cross-bedded sandstone, separated by large water-escape channels (arrow); d Multiple layers showing complex deformations separated by undeformed beds. Note the presence of pseudonodules (arrows) with complexly deformed internal laminae, indicating deformation taking place in multiple phases. Length of the hammer in (b), (c) is $30 \mathrm{~cm}$; length of the pen in (d) is $14 \mathrm{~cm}$

cross beddings, bounded above and below by undeformed topset beds.

\subsubsection{Load and flame structures}

Simple load casts ranging in size from $15 \mathrm{~cm}$ to $35 \mathrm{~cm}$ are present in coarse-grained to relatively finer-grained sandstones (Fig. 10). These load structures appear as large lobes of coarse-grained, poorly-sorted sandstones loading onto the underlying medium- to fine-grained sandstones (Fig. 10a). Laminae in both beds are preserved and gently deformed, conforming to the load structures. Narrow flames in between the loads are of shorter length and height, consist of finer sand and are generally broad-crested (Fig. 10b). Sharp-crested flames are absent, possibly due to the absence of mud. Locally, the flame structures are preserved in foresets of large cross-strata, showing gradational transition from nonloaded to completely-loaded structures.

\subsubsection{Water-escape structures including sedimentary dykes}

Various types of water-escape structures are present within the thick cross-bedded coarse-grained sandstone facies (Fig. 11). Most commonly, these structures are represented by the vertical to inclined columns of coarse- to fine-grained sandstone and/or siltstone formed by the upward movement of sand/silt piercing through layers forming sedimentary dykes (Fig. $11 \mathrm{a}-\mathrm{d}$ ). The upward drag of fluids moving through such columns has caused an upturning of beds/laminae adjacent to the columns (Fig. 11a). Locally a stacking of such upturned concave thin laminae has resulted in dish structures (Fig. 11b, d). Occasionally, sand-dominated vertical protrusions of irregular shapes sharply pierce through thin laminae in a discordant manner, producing multiple parallel sand flows (dykes) of relatively small dimensions with a width and height varying of $6-15 \mathrm{~cm}$ and $65-95 \mathrm{~cm}$ respectively (Fig. $11 \mathrm{~b}, \mathrm{~d}$ ). In some crossstratified sandstone beds, a series of water-escape 

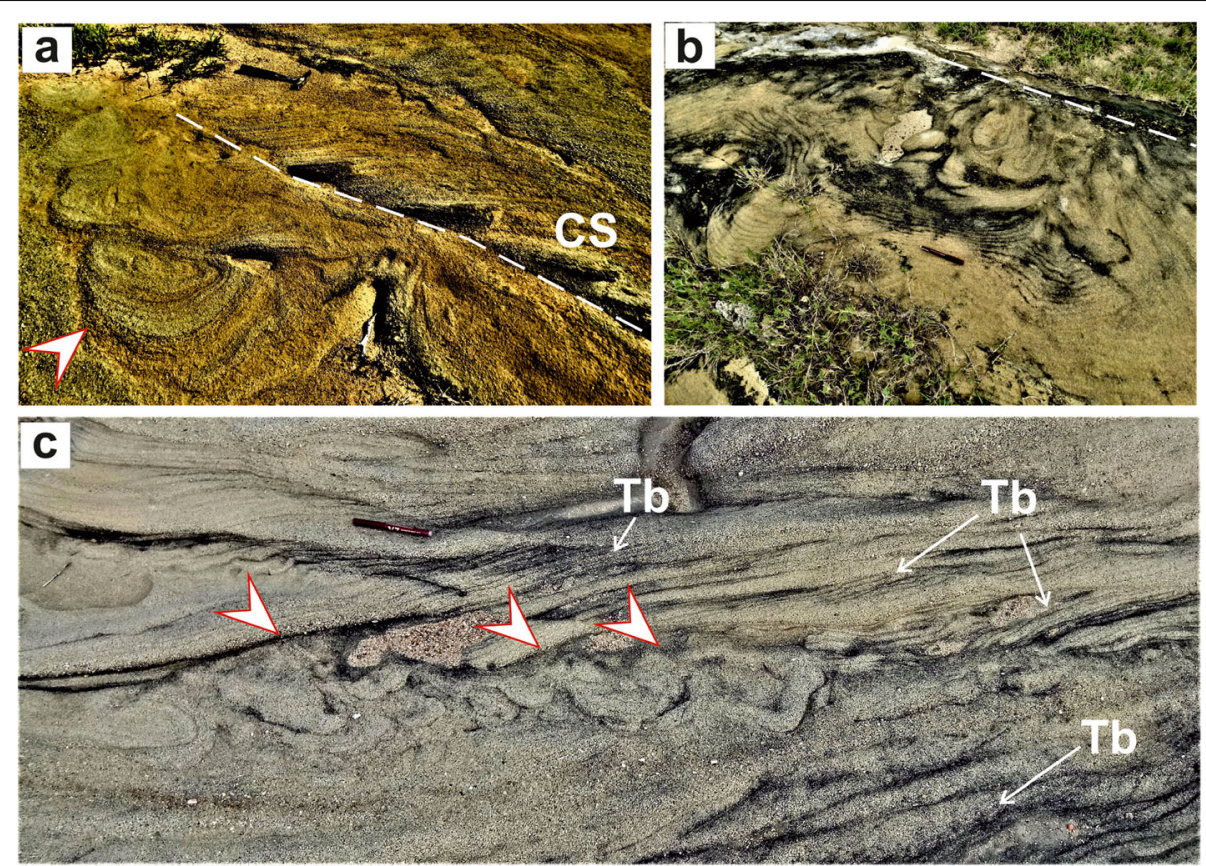

Fig. 8 Field photographs of various complexly deformed layers. a Deformed layers showing stacked multiple lobes (arrow), sharply truncated along the upper boundary (white dashed line) by the overlying undeformed cross-bed sets (CS), within the coarse-grained sandstone; $\mathbf{b}$ Complexly deformed layers within thinly laminated sandstone are truncated along the top sharp boundary. Note the increasing intensity of deformations from periphery to the center of the lobes; c Small-scale multi-lobed deformations within fine-grained cross-stratified heterolithic facies (BM-T2) showing sharp truncation (marked by small white arrows) at the top, overlain by undeformed cross-bed sets characterized by tidal bundles (Tb) of various types. Length of the hammer in (a) is $30 \mathrm{~cm}$; length of the pen in (b), (c) is $14 \mathrm{~cm}$
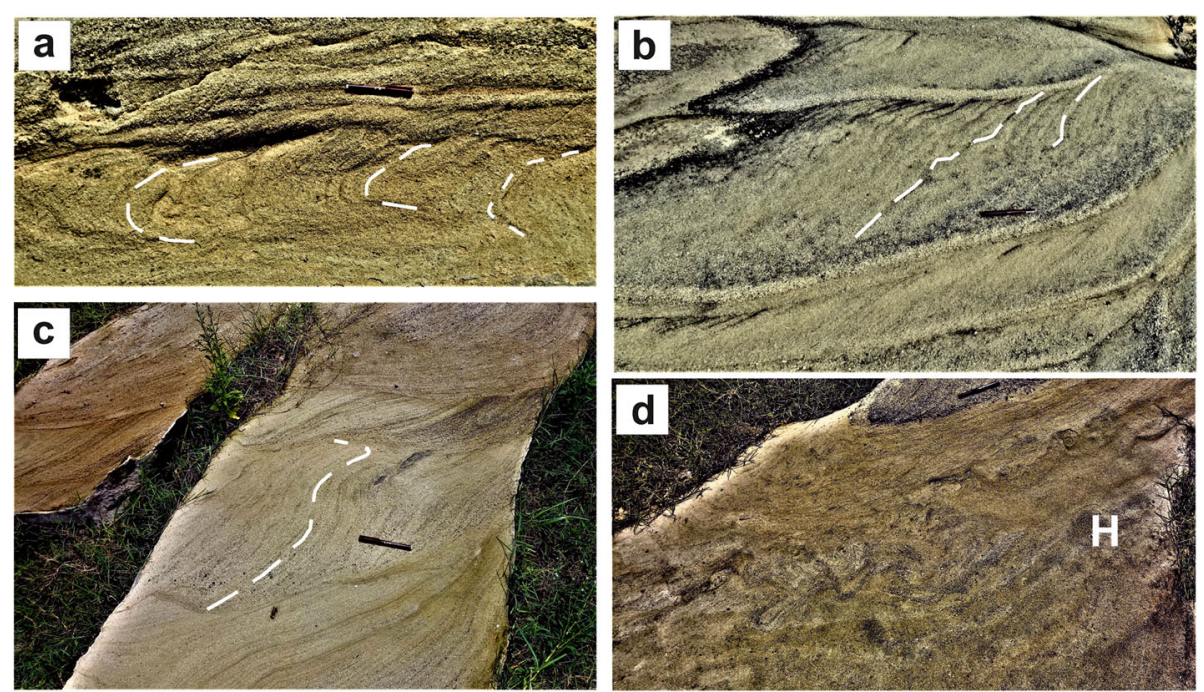

Fig. 9 Field photographs of deformed foresets within cross-strata sets. Some of the foresets are traced with white markings. a Overturned, folded foresets manifesting varied amounts of drag along the top surface; $\mathbf{b}$ Contorted foresets showing minor bulging; $\mathbf{c}$ Folded 'S'-shaped foresets; $\mathbf{d}$ Nearly homogenized $(H)$ foresets. Length of the pen is $14 \mathrm{~cm}$ 


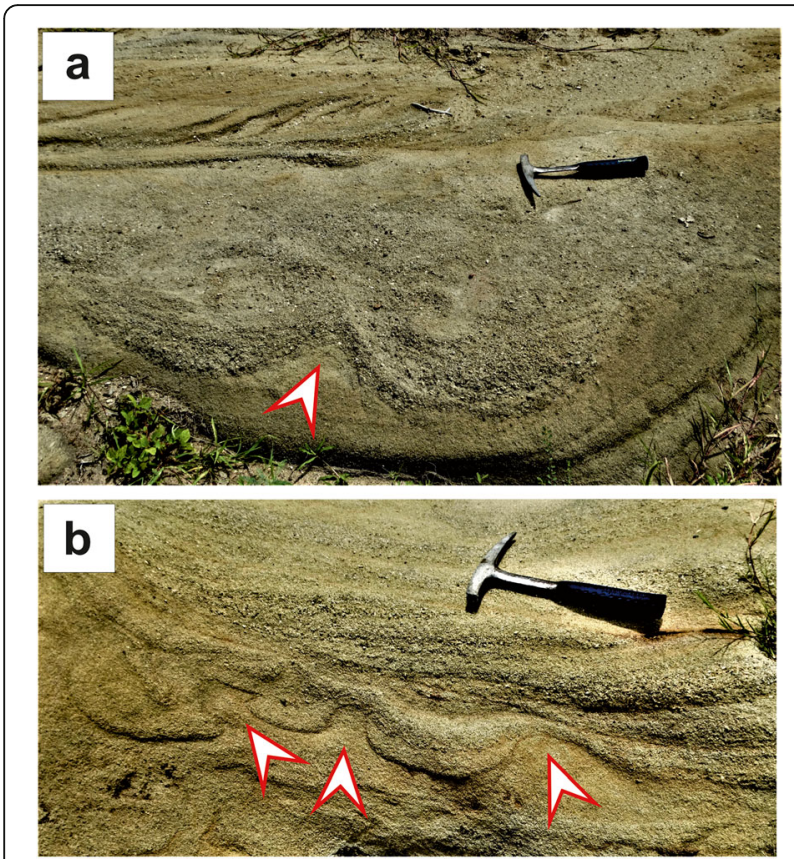

Fig. 10 Field photographs of load and flame structures. a Load structure developed by sagging of coarse-grained sandstone into the underlying fine-grained sandstone. Note the development of a broad flame structure of fine-grained sandstone (arrow); b Multiple load structures developed within one foreset of a coarse-grained cross-stratified sandstone. Intermittent flames of medium-grained sandstone are short, broad-crested, and formed in different orientations (arrows). Length of the hammer is $30 \mathrm{~cm}$

structures has caused contortions of the foresets. Locally, the water-escape columns are absent and instead a series of bulging successive sandstone layers caused by water escaping upwards, leading to a stacked inverted ' $V$ '-like deformation and producing the chevron bending of several layers together (Fig. 11c, e, f). The chevron structures persist laterally up to $20 \mathrm{~cm}$ and vertically up to 40 $\mathrm{cm}$ in a particular location. The position of the chevron structures locally shifts laterally and vertically within the thick foresets of cross-stratified sandstone (Fig. 11e). Such chevron structures are often truncated sharply by the overlying foreset laminae (Fig. 11f).

\subsubsection{Syn-sedimentary faults}

Meter-scale faults confined to specific layers are frequently present in the sandstone-mudstone heterolithic facies, causing truncations and displacements of the deformed laminae (Fig. 12a). The fault traces are 60-125 $\mathrm{cm}$ long in vertical sections showing steeply to gently inclined fault planes. Both normal and reverse faults are present. The faults die out in both upward and downward directions, show upward branching, and manifest greater throw near the base, which is changing to lesser throw upwards (Fig. $12 \mathrm{~b}$-d). These properties of the faults characterize them as growth faults. Locally, the faults have been used as effective pathways of sedimentwater mixtures for their upward moving, then producing complex water-escape structures along the fault planes (Fig. 12 b-d). In the study area, these smaller growth faults do not show any direct relation to the basinal faults. However, the formation of exposure scale small growth faults are very common in similar faultcontrolled basins.

\section{Discussion}

\subsection{Mechanism of deformation}

The confinement of the complex deformations to specific layers (Figs. 5, 6c-f, 8a, c) suggests that the liquefaction took place in particular time intervals (Mohindra and Bagati 1996; Moretti and Sabato 2007). The multilobed character of the complexly deformed layers (Figs. 7a, 8a, b) and the pseudonodules (Figs. 7b, 8c) indicates poly-phase deformation and subsequent liquefaction within short durations while the sediments remain unconsolidated during the deformation (Bhattacharya et al. 2016; Jha et al. 2017). The fluid-escape channels acted as conduits for the upward movement of liquefied sand/silt.

Load casts are formed as a result of an unstable density gradient at the interface between liquefied sediment layers with different bulk density (Owen 2003; Moretti and Sabato 2007; Wang et al. 2011). The final morphology of load structures depends on various parameters such as the duration of the liquidized state, the actual bulk density gradient during deformation, and the kinematic viscosity of the involved sediments (Owen 2003).

Water-escape structures and sedimentary dykes form by upward movement of liquefied and fluidized sediments through some pathways like cracks or voids. Such cracks may develop by shear stress due to pore pressure gradient during liquefaction/fluidization and dewatering. The flow developed by this shear drag and dewatering balances the gravitational force and produces upward flowing sand/silt columns (Fig. 11a, b, d). The development of chevron structures (Fig. 11c, e) suggests localized water escapes at different times. However, the truncated nature of some of the chevron structures (Fig. 11f) attests to the syn-sedimentary nature of the deformation structures, which indicates that the deformation took place before the deposition of the overlying layer although the sedimentation was continuous.

The restricted occurrence of faults (Fig. 12) in specific layers and the presence of undeformed beds above and below indicate their syn-sedimentary origin. Upward and downward flexing of beds due to fault drag and flow of liquefied sand/silt along fault planes (Fig. 12b, d) also point to their syn-sedimentary origin. The development of such faults is often related to volume changes of beds involved in liquefaction and fluidization, commonly 

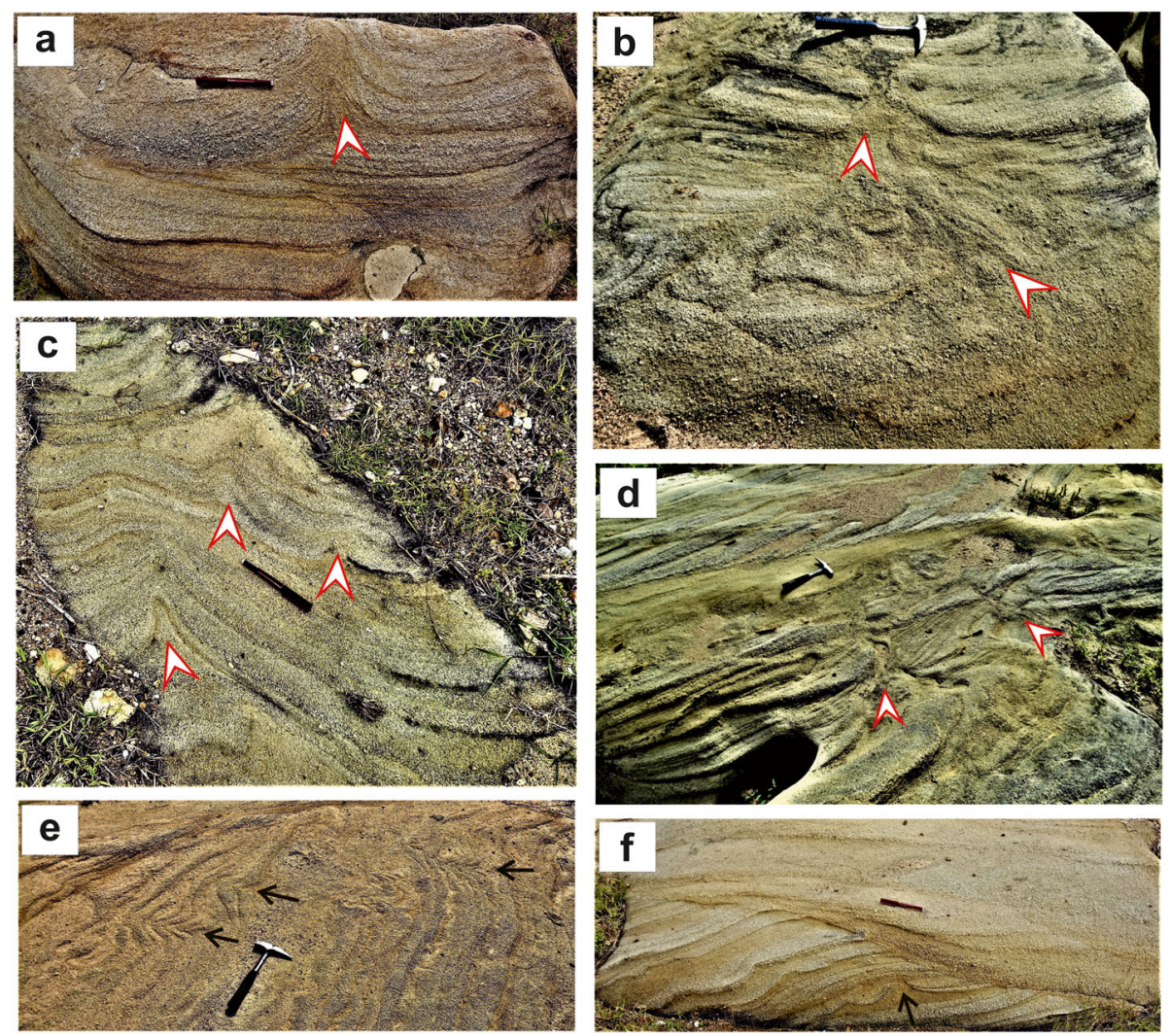

Fig. 11 Field photographs of different types of water-escape structures. a Vertical column of coarse-grained sandstone (arrow) piercing through the overlying beds causing their deformation due to water-escape; $\mathbf{b}$ Inverted funnel-shaped water-escape structure sharply piercing (arrows) across cross-beds; c Upward protrusion of beds producing inverted 'V's (arrows) due to water-escape at different beds at different times; d Sand dykes (arrows) cutting across all overlying layers and mixing with overlying deformed layers; e The bulging successive thick sandstone layers caused by water escaping upwards led to a stacked inverted 'V'-like deformation, producing chevron bending of several layers (black arrows);

f Truncation of a water-escape structure (arrow) by the overlying foreset, indicating the syn-sedimentary nature of the deformation structure. Length of the pen in (a), (c), (f) is $14 \mathrm{~cm}$; length of the hammer in (b), (d), (e) is $30 \mathrm{~cm}$

restricted below large sand volcanoes formed at the sediment-water interface. However, in the present field area, no such direct association has been observed.

\subsection{Driving force}

Following Owen et al. (2011), the principal driving forces for most soft-sediment deformations include: gravitational forces acting along slopes, unequal loading along sediment-water interface, gravitational instabilities, shearing by current and/or biological or chemical disturbances. However, in the present case, in absence of slopes and evidence of biological and chemical disturbances, it can be comprehended that the driving forces behind most of the structures belong to the unequal loading, gravitational instability or shearing by the current. The load and flame structures and the faults are definitely post-depositional. The driving force for the load and flame structures is unequal loading along the sediment-water interface leading to differential liquefaction of the sediments. On the contrary, the driving force for the water-escape structures including sedimentary dykes and complexly deformed layers is gravitational instability and/or current shearing, leading to the upward flow of the liquefied and fluidized sediments. Stratigraphically restricted deformed laminae with undeformed upper and lower boundaries imply syndepositional deformation processes as a result of the current drag on partially liquefied sand, where liquefaction might have been triggered by various agents (Owen 1995; Bhattacharya and Bandyopadhyay 1998). These deformed laminae attest to upward escapes of pore fluids and resettling of grains under an increased fluidpressure head (Owen 1995).

\subsection{Trigger for liquefaction - seismic versus aseismic}

It is well known that besides rapid sedimentation, many other processes like large pounding storm waves, sudden dumping of large sediment gravity flows, slumping along slip planes, or the density contrast due to changes in 

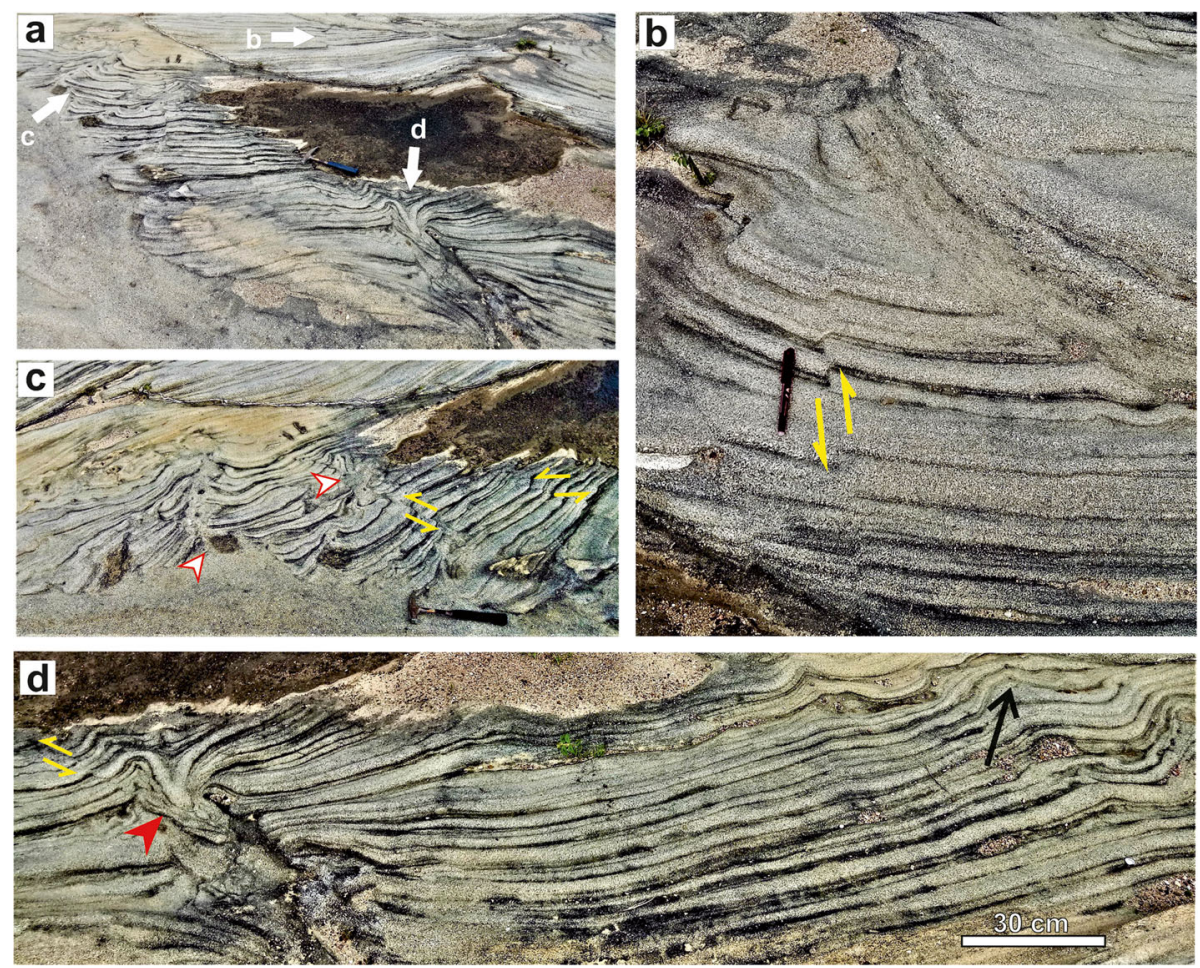

Fig. 12 a Outcrop showing syn-sedimentary faults and associated deformation features. Details of the areas marked by $\mathbf{b}, \mathbf{c}$ and $\mathbf{d}$ are shown in sub-figures (b), (c) and (d), respectively; b Syn-sedimentary fault showing a shifting of laminae (arrows) along the fault plane; c Multiple synsedimentary faults (yellow arrows) showing distinct shifts of the laminae. Note the upward flow of material (sand) (red-white arrow) along the fault plane; $\mathbf{d}$ Upward and downward bending of laminae (red arrow) due to the combined effect of fault dragging (yellow arrows) and fluidescape. Note minor contortions (black arrow) in the laminae at the right end of the photograph. Length of the hammer in (a), (c) is $30 \mathrm{~cm}$; length of the pen in (b) is $14 \mathrm{~cm}$

sediment cohesion and water depth as in tidal flats, may play major roles in triggering liquefaction in unconsolidated sediments. Rare events such as meteorite impacts, volcanic eruptions, tsunami waves or over-steepening of the slopes may also lead to the formation of SSDS (Alvarez et al. 1998; Debacker et al. 2001; Alberti et al. 2017). Apart from these aseismic sources, seismic shocks caused by earthquakes are considered as another possible triggering agent for many of the soft-sediment deformation structures, as propounded by Bhattacharya and Bandyopadhyay (1998), Moretti and Ronchi (2011), Sarkar et al. (2014).

In the studied Barren Measures Formation rocks, detailed sedimentological analysis negates the possibility of most of these aseismic agents as triggers. The supportive reasons for such an argument are listed below:

(1) Facies analysis reveals sedimentation in a high-energy fluvial-dominated setting with some tidal influence (Fig. 2). Signatures of open marine waves including storm waves are not evident in the study area since we have not observed any wave-generated bedforms (e.g., wave ripples, combined flow ripples, etc.) or storm-generated primary sedimentary structures (e.g., hummocky cross-stratification). Thus, the possibility of large pounding waves as triggers for liquefaction is discarded.

(2) Facies architecture reveals the deposition of sediments mostly within channels and flood plains, controlled by fluvial and tidal processes. Distinct facies representing the emplacement of large sediment gravity flows, in the form of thick-bedded massive sandstones or matrix- to clast-supported conglomerates, are not observed in the study area. The absence of such deposits suggests that any type of sediment-gravity flows was absent during the deposition of the studied succession. So the chances of triggering the liquefaction by sudden dumping of large sediment gravity flows seem unlikely.

(3) In the study area, no major or significant evidence of slip planes triggering large-scale slumping of soft unconsolidated sediments, such as creep or slide on a slip plane, is observed. In the study area, the mere absence of such slip planes and the absence of slump structures remove the option for slumping along some slip planes as possible triggers. 
(4) Though tidal sediments are abundant near the middle-upper part of each fining-up cycle, the possibility of a density contrast due to a change in sediment cohesion and water depth, which frequently occurs in tidally influenced settings (tidal flats), seems unlikely there. Such density contrasts commonly form bed-scale deformations (Greb and Archer 2007) and are capable of producing structures as large as those found in the study area (Chiarella et al. 2016). Since the tidal structures found in this study area indicate relatively lower energy conditions of the tidal currents, possibly formed more towards the continental side, a possible role of tidal currents in forming the large deformation structures in the present case can be ruled out.

(5) The sharp truncation of many deformed layers by overlying undeformed beddings signifies the synsedimentary nature of deformations, which indicates deformations taking place at the sedimentwater interface just after the deposition of the affected beds/layers but before the deposition of the overlying beds/foresets. In addition, most of the overlying units are foresets in the large cross-strata, which are deposited one by one and not all at a time. Based on the above discussion, causes like the rapid sedimentation or the density contrast cannot be considered as valid triggering agents.

(6) Another possible factor that can cause a large amount of liquefaction is impact shaking (Alvarez et al. 1998). However, in the study area, no supportive evidence of impact-related shaking is found. These deformation structures also do not match with those described by Alvarez et al. (1998). So the possibility of impact shaking is also discarded.

(7) Volcanic activity can be another possible trigger agent for large liquefaction. But the Gondwana sedimentation, and in particular the sediments of the Barren Measures Formation, were formed in a craton-interior half-graben basin, where no volcanism occurred during sedimentation (Biswas 2003). Thus, the scope of volcanic activities is negated as possible triggering agents for the formation of present SSDS.

(8) Since the signatures of large pounding waves are absent, as discussed earlier, the scope of tsunami waves as possible triggering agents is also not considered as valid.

As the absence of other possible triggering mechanisms as discussed above, earthquakes of variable magnitude in the nearby are considered as an alternative possibility for such deformations. The following features observed in the studied SSDS may be considered as supportive evidence in favor of triggering by earthquakes: (i) Considerably large size of many of the structures (Fig. 7) indicates a large amount of liquefaction, where the entire bed was affected. Such large-scale liquefaction is possible only when a large shaking effect is affecting the beds, like a passing surface seismic wave generated from a nearby epicenter.

(ii) The occurrence of the deformed beds in irregular periodic intervals separated by undeformed crossstratified beds (Fig. 5), indicates recurrent but nonperiodic shaking of the beds. Earthquakes occur in irregular intervals, which will affect the unconsolidated to semi-consolidated sediments repeatedly. The effect will be the strongest close to the sediment-water interface, and will gradually wane downward.

(iii) Heterogeneous assemblages of structures in the beds with upward and lateral changes in the intensity of deformations indicate multiple phases of liquefaction and fluidization by separate individual seismic shocks in response to distinct events (Figs. 7, 11, 12).

(iv) The deformed beds contain an association of different SSDS, viz., large complexly deformed layers (Figs. 6, 7), growth faults with the flow of sediments along fault planes (Fig. 12), and various large water-escape structures including sand/silt flows and chevron up-bulging beds (Fig. 11c, e), which resembles closely with those described already from seismically induced deformed horizons in other areas of the world in terms of appearance and nature of complexity of deformations (Bhattacharya and Bandyopadhyay 1998; Moretti and Sabato 2007). However, the present deformation structures are much larger in dimension than those described as seismically-generated structures from other areas.

All these criteria together point to a seismic origin for most of the soft-sediment deformation structures in this study area. Meanwhile, the beds containing SSDS are identified as 'seismites' based on the following criteria, as listed initially by Owen and Moretti (2011), and later on by Bhattacharya et al. (2016) and Jha et al. (2017): (1) repeated occurrence of the deformed beds in irregular intervals, separated by undeformed beds in stratigraphic section; (2) complex nature of the deformation, evident with multiple phases of deformations in unconsolidated to semi-consolidated stage; (3) association with active fault systems, which may generate earthquakes as potential triggers; (4) gradual increase in the intensity and frequency of deformations near to the epicenter; and, (5) lateral continuity over long distances.

As discussed earlier, the studied SSDS-bearing beds essentially fulfill the above criteria (1), (2) and (3). Biswas 
(2003) proposed early syn-rift conditions during the sedimentation of the Barren Measures Formation, which involved the activation of multiple fault systems in the near vicinity (Fig. 1b). However, the lateral continuity of the beds cannot be traced, as the beds are only exposed in the studied Godavari River section. Based on the present study with detailed documentation of the nature of the deformation structures, we consider that even in the absence of proper evidence of lateral continuity, the studied SSDS-bearing beds represent seismites due to (i) fulfilling most of the characteristic criteria for seismite definition; and, (ii) large size of the deformation features within very coarse-grained sandstones, which needs a high-energy event to liquefy and support the grains in suspension. Furthermore, Moretti and Van Loon (2014) proposed for the possibility of seismites without significant lateral continuity.

\subsection{Implications on palaeodepositional environment and palaeogeography}

Frequent earthquakes caused by repeated reactivations of fault systems are common phenomena in rift basins, including the Gondwana basins (Ghosh 2002; Biswas 2003; Bhattacharya et al. 2016). Repeated reactivation of faults in a rift basin commonly results in the subsidence of basin marginal parts (West 1962). Consequently, seismites caused by fault reactivations are good evidence for the basin marginal subsidence (Bhattacharya et al. 2016; Jha et al. 2017). The concentration of the studied SSDS within the coarser clastics at the base of the cycle supports the repeated reactivation of faults in the halfgraben-type Pranhita-Godavari Valley and the consequent sagging of the basin during the sedimentation of the Barren Measures Formation. Due to the half-graben nature of the basin, each sagging resulted in more space in terms of rising the base level, and then caused the onlap of the tidal-influenced depositional system over the fluvial system. This onlap did not hamper the fluvial supply but changed the ratio of suspension fallout over the bedload deposit in the progressive basin filled sediments, with the landward side remaining undisturbed tectonically. Thus, the landward incursions of tidal currents associated with the basinward sagging resulted in fluvial to fluvio-tidal transgressive successions within the early syn-rift tectono-sedimentary setting.

\section{Conclusions}

The long-standing debate on the actual designation of 'seismites' rests on the identification and demarcation of certain parameters, as described by Owen and Moretti (2011), and further analyzed by Moretti and Van Loon (2014). The soft-sediment deformation structures in the Barren Measures Formation in the Pranhita-Godavari Valley are distinct as they are unusually large, very complex and occur mostly in pebbly, coarse-grained sandstones. The truncated, syn-sedimentary nature of these structures signifies that the trigger for liquefaction was confined at or near to the sediment-water interface before the deposition of the next overlying bed. In the absence of other possible triggering mechanisms, such instantaneous, quick shaking causing huge amount of liquefaction could be caused by earthquake shocks only. The studied SSDS-bearing beds thus lead us to a new paradigm for defining seismites, which is actually a minor modification of the list of criteria proposed by Owen and Moretti (2011). Thus, the occurrence of extremely large SSDS, mostly truncated at the top by overlying undeformed beds, developed in very coarse-grained sediments can also be counted as an important parameter for identifying earthquake shocks, even if some of the criteria (e.g., lateral persistence) listed by Owen and Moretti (2011) are missing.

In addition, the studied seismites of the Barren Measures Formation in the Pranhita-Godavari Valley imply that:

(1) Seismic shocks triggered by earthquakes of moderate to high magnitude were frequent and led to instantaneous liquefaction and fluidization of unconsolidated sediments.

(2) Earthquakes were triggered by syn-sedimentary fault reactivations.

(3) The occurrence of seismites in a succession with upward increasing effects of marine influence attests to a close link between sedimentation and fault-induced basinal subsidence.

(4) The present seismites signify as one kind of marker to an active syn-rift tectono-sedimentary setting in the eastern Peninsular India during the Permian.

\section{Acknowledgements}

The authors thank Indian Institute of Technology, Roorkee for providing the research facilities. Authors are also grateful to three anonymous reviewers for critical and painstaking review on the manuscript. BB is thankful to Prof. Zeng-Zhao Feng, the Editor-in-Chief, for considering the paper for an oral presentation in the $4^{\text {th }}$ International Conference of Palaeogeography and for publication in the Journal of Palaeogeography.

\section{Authors' contributions}

BB participated in the fieldwork, identified and interpreted the structures, conceptualized the academic problem and drafted the manuscript. AS participated in the fieldwork, carried out the detailed descriptions of SSDS, prepared the log, and drafted the manuscript. Both the authors have read and approved the final manuscript.

\section{Funding}

This research work was supported by the Institute (MHRD) Fellowship provided to AS by the Indian Institute of Technology, Roorkee, India.

\section{Availability of data and materials}

The authors declare that the materials in this study are available in public to be openly accessed by anyone. All data are collected by the authors themselves through fieldwork followed by laboratory analysis and nothing has been supplied by any other person or organization. 


\section{Competing interests}

The authors declare that they have no competing interests. The authors alone are responsible for the content and writing of this article.

Received: 26 September 2019 Accepted: 8 April 2020

Published online: 29 May 2020

\section{References}

Alberti, M., D.K. Pandey, J.K. Sharma, N.K. Swami, and A. Uchman. 2017. Slumping in the upper Jurassic Baisakhi formation of the Jaisalmer Basin, western India: Sign of synsedimentary tectonics? Journal of Palaeogeography 6 (4): 321-332.

Alfaro, P., L. Gibert, M. Moretti, F.J. Garcia-Tortosa, C. Sanz de Galdeno, J. Galíndo-Zaldivar, and Á.C. López-Garrido. 2010. The significance of giant seismites in the Plio-Pleistocene Baza palaeo-lake (S Spain). Terra Nova 22 (3): 172-179.

Alfaro, P., M. Moretti, and J.M. Soria. 1997. Soft-sediment deformation structures induced by earthquakes (seismites) in Pliocene lacustrine deposits (Guadix-Baza Basin. Central Betic cordillera). Eclogae Geologicae Helvetiae 90 (3): 531-540.

Allen, J.R.L. 1977. The plan shape of current ripples in relation to flow conditions. Sedimentology 24: 53-62.

Allen, J.R.L. 1982. Sedimentary structures their character and physical basis. In Developments in sedimentology 30B. Amsterdam: Elsevier.

Allen, J.R.L. 1985. Wrinkle marks: An intertidal sedimentary structure due to aseismic soft-sediment loading. Sedimentary Geology 41: 75-95.

Alvarez, W., E. Staley, D. O'Connor, and M.A. Chan. 1998. Synsedimentary deformation in the Jurassic of southeastern Utah-a case of impact shaking? Geology 26 (7): 579-582.

Bhattacharya, B., S. Bandyopadhyay, S. Mahapatra, and S. Banerjee. 2012. Record of tide-wave influence on coal-bearing Permian Barakar formation, Raniganj Basin, India. Sedimentary Geology 267-268: 25-35.

Bhattacharya, B., and P.P. Banerjee. 2015. Record of Permian Tethyan transgression in eastern India: A reappraisal of the barren measures formation, West Bokaro coalfield. Marine and Petroleum Geology 67: 170-179.

Bhattacharya, B., J. Bhattacharjee, S. Banerjee, S. Bandyopadhyay, and R. Das. 2016. Seismites in Permian Barakar formation, Raniganj Basin, India: Implications on lower Gondwana basin evolution. Arabian Journal of Geosciences 9: 1-13.

Bhattacharya, B., J. Bhattacharjee, S. Banerjee, S. Banerjee, and K. Adhikary. 2018. Early Permian transgressive-regressive cycles: Sequence stratigraphic reappraisal of the coal-bearing Barakar formation, Raniganj Basin, India. Journal of Earth System Sciences 127: 29.

Bhattacharya, H.N., and S. Bandyopadhyay. 1998. Seismites in a Proterozoic tidal succession, Singhbhum, Bihar, India. Sedimentary Geology 119: 239-252.

Bhattacharya, H.N., and B. Bhattacharya. 2010. Soft-sediment deformation structures from an ice-marginal storm-tide interactive system, Permocarboniferous Talchir formation, Talchir coal basin, India. Sedimentary Geology 223: 380-389.

Bhattacharya, H.N., and B. Bhattacharya. 2015. Lithofacies architecture and paleogeography of late Paleozoic glaciomarine Talchir formation, Raniganj Basin, India. Journal of Palaeogeography 4 (3): 269-283.

Bhattacharya, H.N., A. Chakraborty, and B. Bhattacharya. 2005. Significance of transition between Talchir formation and Karharbari formation in lower Gondwana basin evolution - A study in West Bokaro Coal Basin, Jharkhand, India. Journal of Earth System Sciences 114 (3): 275-286.

Biswas, S.K. 2003. Regional tectonic framework of the Pranhita-Godavari Basin, India. Journal of Asian Earth Sciences 21: 543-551.

Brodzikowski, K., and A. Haluszczak. 1987. Flame structures and associated deformations in Quaternary glacio-lacustrine and glacio-deltaic deposits: Examples from central Poland. In Deformation of sediments and sedimentary rocks, Special Publications 29, ed. M.E. Jones and R.M.F. Preston, 279-286. London: Geological Society.

Chiarella, D., M. Moretti, S.G. Longhitano, and F. Muto. 2016. Deformed cross-stratified deposits in the Early Pleistocene tidally-dominated Catanzaro strait-fill succession, Calabrian arc (southern Italy): Triggering mechanisms and environmental significance. Sedimentary Geology 344: 277-289.

Debacker, T.N., M. Sintubin, and J. Verniers. 2001. Large-scale slumping deduced from structural and sedimentary features in the lower Palaeozoic Anglo-Brabant fold belt, Belgium. Journal of the Geological Society 158 (2): 341-352.

Ghosh, S.C. 2002. The Ranigunj Coal Basin: An example of an Indian Gondwana rift. Sedimentary Geology 147: 155-176.

Gibert, L., C.S. De Galdeano, P. Alfaro, G. Scott, and A.L. Garrido. 2005. Seismic-induced slump in Early Pleistocene deltaic deposits of the Baza Basin (SE Spain). Sedimentary Geology 179 (3-4): 279-294.

Greb, S.F., and A.W. Archer. 2007. Soft-sediment deformation produced by tides in a meizoseismic area, Turnagain arm, Alaska. Geology 35: 435-438.

Jha, S., B. Bhattacharya, and S. Nandwani. 2017. Significance of seismites in the late cretaceous transgressive Nimar sandstone succession, sonNarmada rift valley, Central India. Geological Journal 52: 768-783.

Lakshminarayana, G. 1996. Stratigraphy and structural framework of Gondwana sediments in Pranhita-Godavari Valley, Andhra Pradesh. In Gondwana Nine 1, 9th International Gondwana Symposium, Hyderabad, India, 1994, 311-330. New Delhi: Oxford and IBH Publishing Co. (P) Ltd.

Lowe, D.R. 1975. Water escape structures in coarse-grained sediments. Sedimentology 22: 157-204.

Maulik, P.K., and A.K. Chaudhuri. 1983. Trace fossils from continental Triassic red beds of the Gondwana sequence, Pranhita-Godavari Valley, South India. Palaeogeography, Palaeoclimatology, Palaeoecology 41: 17-34.

Mohindra, R., and T.N. Bagati. 1996. Seismically induced soft-sediment deformation structures (seismites) around Sumdo in the lower Spiti valley (Tethys Himalaya). Sedimentary Geology 101 (1-2): 69-83.

Moretti, M., P. Alfaro, and G. Owen. 2016. The environmental significance of soft-sediment deformation structures: Key signatures for sedimentary and tectonic processes. Sedimentary Geology 344: 1-4.

Moretti, M., and A. Ronchi. 2011. Liquefaction features interpreted as seismites in the Pleistocene fluvio-lacustrine deposits of the Neuquén Basin (northern Patagonia). Sedimentary Geology 235 (3-4): 200-209.

Moretti, M., and L. Sabato. 2007. Recognition of trigger mechanisms for softsediment deformation in the Pleistocene lacustrine deposits of the Sant'Arcangelo Basin (southern Italy): Seismic shock vs. overloading. Sedimentary Geology 196 (1-4): 31-45.

Moretti, M., and A.J. Van Loon. 2014. Restrictions to the application of 'diagnostic' criteria for recognizing ancient seismites. Journal of Palaeogeography 3 (2): 162-173.

Obermeier, S.F. 1996. Use of liquefaction-induced features for paleoseismic analysis - An overview of how seismic liquefaction features can be distinguished from other features and how their regional distribution and properties of source sediment can be used to infer the location and strength of Holocene paleo-earthquakes. Engineering Geology 44: 1-76.

Obermeier, S.F., S.M. Olson, and R.A. Green. 2005. Field occurrences of liquefaction-induced features: A primer for engineering geologic analysis of paleoseismic shaking. Engineering Geology 76: 209-234.

Owen, G. 1987. Deformation processes in unconsolidated sands. In Deformation of Sediments and Sedimentary Rocks, Special Publications 29, ed. M.E. Jones and R.M.F. Preston, 11-24. London: Geological Society.

Owen, G. 1995. Soft sediment deformation in upper Proterozoic Torridonian sandstones, Applecross formation at Torridon, Northwest Scotland. Journal of Sedimentary Research 65: 495-504.

Owen, G. 2003. Load structures: Gravity-driven sediment mobilization in the shallow subsurface. In Subsurface Sediment Mobilization, Special publications 216., ed. P. Van Rensbergen, R.R. Hillis, A.J. Maltman, and C. K. Morley, 21-34. London: Geological Society.

Owen, G., and M. Moretti. 2008. Determining the origin of soft-sediment deformation structures: A case study from upper carboniferous delta deposits in south-West Wales. Terra Nova 20: 237-245.

Owen, G., and M. Moretti. 2011. Identifying triggers for liquefactioninduced soft-sediment deformation in sands. Sedimentary Geology 235: 141-147. 
Owen, G., M. Moretti, and P. Alfaro. 2011. Recognising triggers for softsediment deformation: Current understanding and future directions. Sedimentary Geology 235: 133-140.

Postma, G. 1983. Water escape structures in the context of a depositional model of a mass flow dominated conglomeratic fan-delta. Abrioja formation, Pliocene, Almeria Basin, SE Spain. Sedimentology 30: 91-103.

Pratt, B.R. 1994. Seismites in the Mesoproterozoic Altyn formation (belt Supergroup), Montana: A test for tectonic control of peritidal carbonate cyclicity. Geology 22: 1091-1094.

Raja Rao, C.S. 1982. Coalfields of India, Vol. II. Coal resources of Tamil Nadu, Andhra Pradesh, Orissa and Maharashtra. Bulletin of the Geological Survey of India 45 (A): 41-52.

Rodríguez-Pascua, M.A., J.P. Calvo, G. De Vicente, and D. Gómez-Gras. 2000. Soft-sediment deformation structures interpreted as seismites in lacustrine sediments of the Prebetic zone, SE Spain, and their potential use as indicators of earthquake magnitudes during the Late Miocene. Sedimentary Geology 135: 117-135.

Rossetti, D.F. 1999. Soft-sediment deformation structures in late Albian to Cenomanian deposits, Sao Luís Basin, northern Brazil: Evidence for paleoseismicity. Sedimentology 46: 1065-1081.

Sarkar, S., A. Choudhuri, S. Banerjee, A.J. Van Loon, and P.K. Bose. 2014 Seismic and non-seismic soft-sediment deformation structures in the Proterozoic Bhander limestone, Central India. Geologos 20: 79-93.

Seilacher, A. 1969. Fault-graded beds interpreted as seismites. Sedimentology 13: $155-159$

Seilacher, A. 1984. Sedimentary structures tentatively attributed to seismic events. Marine Geology 55: 1-12.

Sengupta, S. 2003. Gondwana sedimentation in Pranhita-Godavari Valley: A review. Journal of Asian Earth Sciences 21: 633-642.

Seth, A., S. Sarkar, and P.K. Bose. 1990. Synsedimentary seismic activity in an immature passive margin basin, lower member of Katrol formation, upper Jurassic, Kutch, India. Sedimentary Geology 68: 279-291.

Sharan, P.S., and K. David. 2016. An overview of Pranhita-Godavari sedimentary basin, Telangana, India. International Research Journal of Natural and Applied Sciences 3: 132-147.

Sims, J.D. 1973. Earthquake-induced structures in sediments of Van Norman Lake, San Fernando, California. Science 182: 161-163.

Van Loon, A.J. 2014. The life cycle of seismite research. Geologos 20: 61-66.

Wang, P., B. Zhang, W. Qiu, and J. Wang. 2011. Soft-sediment deformation structures from the Diexi paleodammed lakes in the upper reaches of the Minjiang River, East Tibet. Journal of Asian Earth Sciences 40 (4): 865 872

West, W.D. 1962. The line of the Narmada and son valleys. Current Science 31: 143-144.

\section{Publisher's Note}

Springer Nature remains neutral with regard to jurisdictional claims in published maps and institutional affiliations.

\section{Submit your manuscript to a SpringerOpen ${ }^{\circ}$ journal and benefit from:}

- Convenient online submission

- Rigorous peer review

- Open access: articles freely available online

- High visibility within the field

- Retaining the copyright to your article

Submit your next manuscript at $\boldsymbol{\nabla}$ springeropen.com 